\title{
Navigáció alkalmazása az implantológiában: Összefoglaló áttekintés a pontossági adatok alapján
}

\author{
DR. BARRAK IBRAHIM ÁDÁM*, IFJ. DR. VARGA ENDRE**, DR. PIFFKÓ JÓZSEF*
}

\begin{abstract}
A vizsgálat célkitúzése a statikus navigációs rendszerek pontosságának elemzése volt a nemzetközi irodalmi adatok alapján. Elektronikus irodalomkutatást végezve 661 publikációt találtunk a témában. A keresési feltételeknek legjobban megfelelő 139 absztrakt áttekintését követően 52 publikáció teljes elemzéséből 24 olyan tanulmányt választottunk ki, amelyek az implantátumok pozíciójának pontosságára vonatkozó adatokat tartalmaztak. A kiválasztott források közül tizennégy klinikai, tíz pedig in vitro (modell, cadaver) vizsgálat volt. Az adatok összehasonlítását varianciaanalízissel (Tukey-féle post-hoc teszt; $p<0,05$ ) végeztük. 2819 esetet összesítve a belépési értékek átlaga 0,98 mm volt. Az apikális eltérések tekintetében ez a szám 1,29 mm volt, míg a szögeltéréseket vizsgálva 3,96-ot kaptunk eredményül. Szignifikáns eltérést sikerült kimutatni az egyes behelyezési (részlegesen, és teljesen sablon által irányított) módszerek között az apikális távolság, belépési eltérés és a szögeltérés alapján. Az egyes paraméterek további vizsgálatára egy, illetve több vizsgálati központban zajló randomizált, kontrollált klinikai kísérletek szükségesek, amelyek megfelelnek az evidencia alapú tudás követelményeinek.
\end{abstract}

Kulcsszavak: implantológia, számítógépes tervezés, navigáció, implantációs sablon

A dentális implantáció a modern orális rehabilitáció szerves része, és az ennek hátterében álló osseointegrációs folyamatokat már több évtizede eredményesen kutatják [15, 24]. A különféle csontregenerációs technikáknak köszönhetően ma már olyan pácienseknél is sikeres lehet az implantáció, akiknél korábban implantációra alkalmatlannak ítélt anatómiai adottságokkal (jelentős csontpusztulás, nem megfelelő csontállomány) találkozott a kezelőorvos [5, 13]. Ezen technikák, illetve a fogászati és egyéb digitális technológiák fejlődésének köszönhetően a protetikai szempontból is megfelelően pozicionált dentális implantátumok behelyezése technikailag egyre biztosabbá válik. Az optimális implantátumpozíció számos előnnyel rendelkezik. Lehetővé teszi optimális fogpótlás elkészítését azáltal, hogy megteremti a helyes okklúzió és terhelés feltételeit, valamint elősegíti a protetikai és esztétikai helyreállítást. Az optimális helyzetben lévő implantátum túlélésének egyik legfontosabb feltétele, hogy körülötte három dimenzióban megfelelő mennyiségú és minőségú csont helyezkedjen el. Tehát az implantátum pozicionálásának kiemelkedő jelentősége van, emellett hozzájárulhat egy hosszú távon sikeres rehabilitációhoz.

A „cone-beam” komputertomográfia (CBCT) térnyerése az orális implantológiában áttörést eredményezett, hiszen ennek a háromdimenziós képet biztosító eszköznek a használata gazdaságosabb és kisebb sugárterheléssel jár, mint a hagyományos komputertomográf (CT) berendezéseké [11, 14, 18]. Tervező szoftverrel párosítva, a CBCT képek felhasználása lehetővé teszi, hogy virtuálisan megtervezze a kezelőorvos az implantátum méreteit és helyzetét, különös tekintettel a környező anatómiai struktúrákra és a fogpótlástani elvárásokra [38]. Az említett tervezési folyamat eredményeit többféle módon lehet a digitális környezetből a valós klinikai szituációba átültetni. A tervezett implantátum-pozíciókat implantációs sablonokon, vagy valós idejü navigációs rendszer formájában lehet a klinikai környezetbe átvinni, és ott alkalmazni. Jung és mtsai ezeket a módszereket statikus és dinamikus eljárásoknak nevezték el, melyek azóta bevett nómenklatúraként kerülnek használatra [16]. Statikusak azok a rendszerek, melyek az előre meghatározott implantátum pozícióját implantációs sablonon keresztül valósítják meg. Ezzel szemben a dinamikus rendszerek a tervezett implantátumpozíció, a kézidarab, és a páciens képének egymáshoz viszonyított helyzetét egy számítógép monitorján keresztül közvetítik az operáló személy/személyzet számára. A valós idejü beavatkozást megvalósító rendszerekről jelenleg sokkal kevesebb adat áll rendelkezésre [12]. Ezek a rendszerek ma még rendkívül költségesek, használatuk nehézkes, és nem biztosítanak megfelelö taktilis érzetet az operáló személy számára. Fenti okok miatt, jelen tanulmányban a szerzők a statikus rendszerekre, azaz a sebészi sablonok használatára koncentrálnak. 
A különböző statikus rendszereket az implantációs fúróknak a vezetési tulajdonságai és az implantátum behelyezése alapján különíthetjük el. Ezáltal a statikus navigációnak három formáját különböztetjük meg:

- pilot megvezetés, pilot fúró használata, ami az implantátum fészkét legkisebb átmérőben teljes mélységben munkálja meg;

- részleges megvezetés, aminek során a furat legnagyobb dimenziójának kialakítása történik, de az implantátum behelyezése szabad kézzel történik $[7,8,10]$;

- teljes megvezetés: mind a furat kialakítása, mind pedig az implantátum behelyezése sablonon keresztül valósul meg [22, 28-30].

Ezenkívül a tervezett, és a ténylegesen behelyezett implantátumok pozícióinak összevetésére különféle pontosság-mérési technikák és metódusok lelhetők fel az irodalomban. Némely forrás alapvonalbeli méréseket használ, mint a koronális és apikális pontok közötti méréseket. Mások térbeli, 3 dimenziós méréseket végeztek (x, y, z tengelyek mentén) [31]. A fent említett tulajdonságok összessége az egyes rendszerek közötti összehasonlítást, valamint az egységes áttekintést nehezíti meg.

Tanulmányunk célkitǔzése, hogy a rendelkezésre álló irodalmat rendszerezzük a különféle pontossági mérések alapján, és egy összefoglaló áttekintést hozzunk létre.

\section{Anyag és módszer}

Elektronikus irodalomkutatást végeztünk a PubMed adatbázisában. A keresőben általunk használt szavak: dental, implant, implants, guid", compute ${ }^{*}$ voltak. A keresés az 1966-tól 2015-ig tartó időszakot ölelte fel [12, 16, 31]. A kiválasztás alapjait a 2009. évi és a 2014. évi International Team for Implantology (ITI) általi megegyezésen alapuló irányelvek [16, 31], valamint a 2015. évi European Association for Osseointegration (EAO) útmutatásai [12] képezték.

Ez a tanulmány azokat a statikus rendszerekről szóló forrásokat tartalmazza, melyeknél az összehasonlítást CT/CBCT felvételek alapján valósították meg. Nem vettük figyelembe azokat a publikációkat, melyek járomcsonti, ékcsonti, valamint orthodonciai implantátumokkal foglalkoztak. Azokat az elemzéseket tekintettük át, ahol vizsgálták a tervezett és a behelyezett implantátum-pozíciók közötti távolságbeli és szögeltéréseket. A klinikai vizsgálatoknak legalább 5 pácienst kellett tartalmazniuk.

További alcsoportokat különböztettünk meg az alábbi feltételek alapján:

- A beavatkozáson átesett állcsontok fogazati státusza: teljes fogatlanság, részleges foghiány;

- Maxilla vagy mandibula;

- Lebenyképzéssel járó vagy transzgingivális mútéti technika;

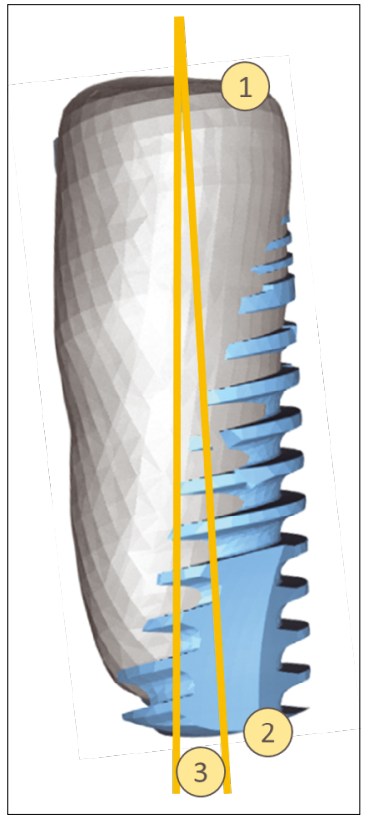

1. ábra: Tervezett és behelyezett implantátumok helyzetének összehasonlítására szolgáló pontok:

1. Belépési pont, 2. Apikális pont, 3. Szögeltérés

- A használt sablon megtámasztása, elhorgonyzása: nyálkahártya, nyálkahártyán rögzítötüskékkel, csont, fogak, mini-implantátumok;

- Az implantátum behelyezésének módszere alapján: részleges vagy teljes megvezetés (ld. fent);

- A tanulmány kivitelezése alapján: klinikai, cadaver, modell.

A tervezett és a beültetett implantátum helyzete közötti összehasonlítására, azaz a beavatkozások pontosságának megállapítására a legtöbb tanulmányban a következő mérőpontokat, referenciapontokat használtuk fel:

- A belépési pontnál lévő eltérés, melyet az implantátum koronális végének közepén mértek;

- Az implantátum csúcsánál található differencia, melyet az implantátum apikálisan lévő végének centrumában vizsgáltak;

- Szögbeli eltérés, melyet a tervezett és a megvalósult implantátum tengely-állásának az összehasonlításából lehet mérni (1. ábra).

A különféle publikációkban kapott eredmények egymással történő összevetése csak akkor lehetséges, ha a mérési módok ugyanazon paraméterek mentén történtek. Ennek elérése érdekében a Tahmaseb és mtsai által leírt módszereket használtuk [31]. A koronális és apikális referenciapontoknál történt mérések az esetek többségében hasonló módon lettek kivitelezve. A szögeltéréseket az elemzések fokban adták meg. A tervezett és a már behelyezett implantátumok közötti távolságok 3D-ban láthatók. Bizonyos szerzők különbséget tettek az egyes tengelyek között, ennek megfelelöen az $x$ tengely a bukko-lingvális, az y tengely a mezio-disz- 


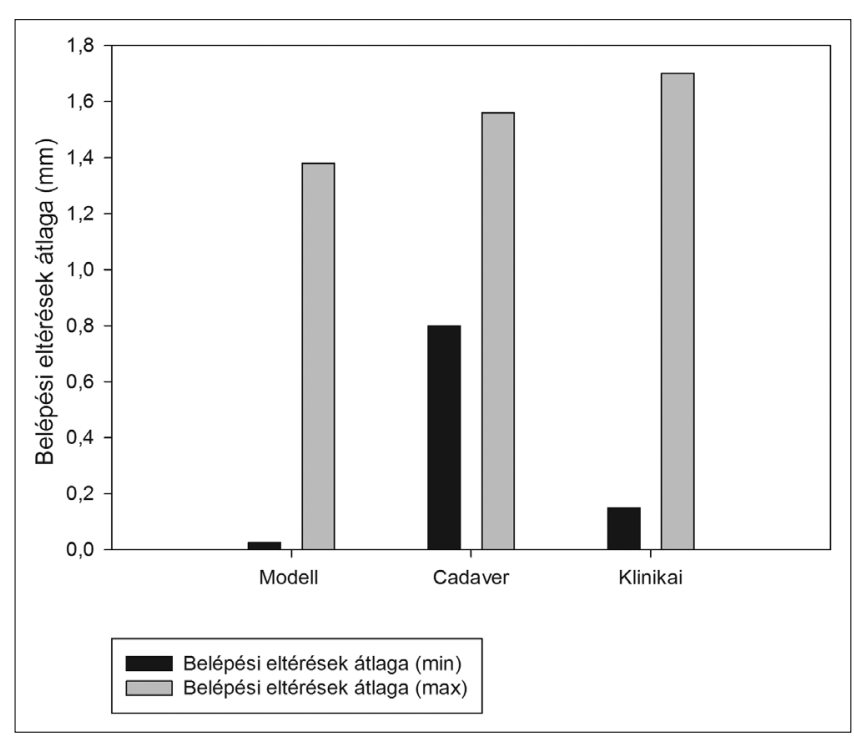

2. ábra: Belépési eltérések átlaga

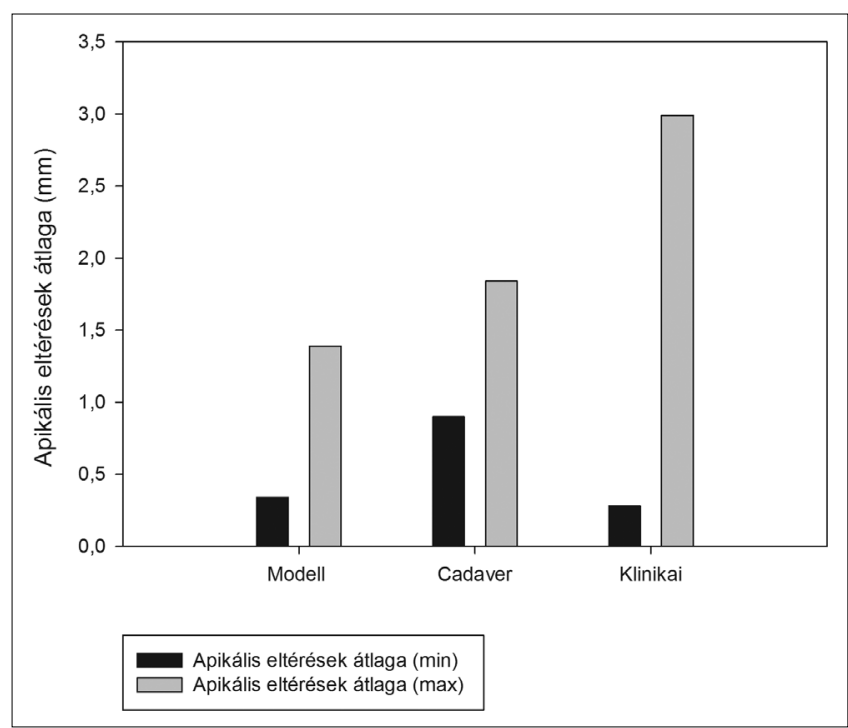

3. ábra: Apikális eltérések átlaga

tális, míg a z tengely az apiko-koronális irányú kiterjedéseket jelentették [31].

\section{Statisztikai analízis}

Az eredmények statisztikai értékelésére a minták nagyobb száma, valamint a különféle kategóriák alapján történő összehasonlítás miatt variancia analízist (ANOVA) végeztünk, post-hoc Tukey tesztet. Az eredményeket $p<0,05$ esetén szignifikánsnak tekintettük.

\section{Eredmények}

A kezdeti keresés alapján 661 találatot kaptunk. Ebből 139 releváns absztraktot választottunk ki, melyek meg-

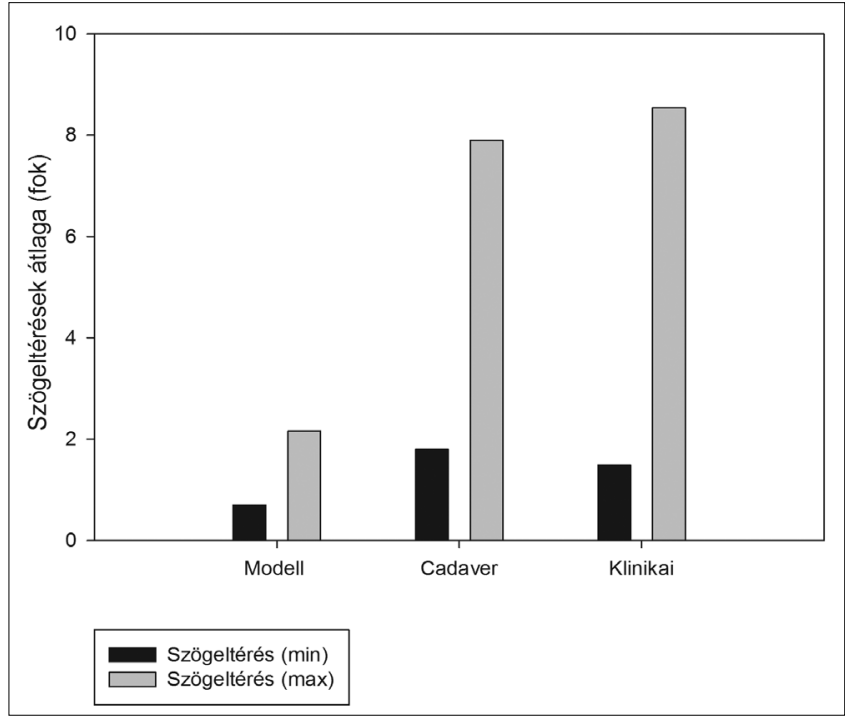

4. ábra: Szögeltérések átlaga

I. táblázat

24 értekezés részletes elemzése

\begin{tabular}{|l|c|}
\hline Rendszer & Publikációk száma \\
\hline SimPlant & 6 \\
\hline Nobel Guide & 6 \\
\hline StentCad & 4 \\
\hline coDiangostiX & 2 \\
\hline Exe-plan & 2 \\
\hline NeoGuide & 2 \\
\hline Beyond & 1 \\
\hline Implant 3D & 1 \\
\hline Implant Viewer & 1 \\
\hline Facilitate & 1 \\
\hline
\end{tabular}

feleltek a kritériumoknak. Ezt követően a szerzők átbeszélve, ezen publikációk közül 52 tanulmányt választottak ki a teljes körű áttekintésre.

Összességében, fenti kritériumok alkalmazása után 24 értekezés került kiválasztásra a részletes elemzés céljából (I. táblázat).

A források közül tizennégy klinikai, tíz pedig in vitro (modell, cadaver) vizsgálat volt. Az implantátumok száma az egyes vizsgálatokat tekintve 9 és 139 között változott a klinikai értékeléseket tekintve, míg a modell és cadaver elemzéseket tekintve ez a szám 4 és 145 volt. A felhasznált rendszerek számát nézve 9 rendszert különböztettünk meg, ezeket az információkat a II. táblázatban foglaltuk össze.

A tanulmányok kivitelezésének módjait vizsgálva kapott eredményeink a következök voltak:

Modell tanulmányok: 74 esetben tapasztaltunk a belépési pontnál mért eltérést. $\mathrm{Az}$ itt kapott átlagos eltérések közötti különbség 0,025 és 1,38 mm között volt. 
A felhasznált 9 rendszer információinak összefoglalása

\begin{tabular}{|c|c|c|c|c|c|c|}
\hline Szerzők & Év & $\begin{array}{l}\text { Tanulmány } \\
\text { kivitelezése }\end{array}$ & Rendszer & Fogazat állapota & Állcsont & $\begin{array}{l}\text { Sablon megtámasztása } \\
\text { (csont/fog/nyálkahártya) }\end{array}$ \\
\hline van Steenberghe és mtsai. [33] & 2002 & Cadaver & Nobel Guide & Teljes foghiány & Maxilla & Csont \\
\hline Di Giacomo és mtsai. [7] & 2005 & Klinikai & SimPlant & Részleges foghiány & Mindkettő & Csont/Fog \\
\hline van Assche és mtsai. [32] & 2007 & Cadaver & Nobel Guide & Részleges foghiány & Mindkettő & Fog+2x rögzítőtüske \\
\hline \multirow[t]{11}{*}{ Ersoy és mtsai. [10] } & 2008 & Klinikai & StentCad & Mindkettő (részleges és teljes foghiány) & Mindkettő & Kombinált (nyálkahártya/csont/fog) \\
\hline & & & & Teljes foghiány & Mindkettő & Kombinált (nyálkahártya/csont/fog) \\
\hline & & & & Részleges foghiány & \begin{tabular}{|l|} 
Mindkettő \\
\end{tabular} & Kombinált (nyálkahártya/csont/fog) \\
\hline & & & & Egy fog hiánya & Mindkettő & Kombinált (nyálkahártya/csont/fog) \\
\hline & & & & Mindkettő (részleges és teljes foghiány) & \begin{tabular}{|l|} 
Mindkettő \\
\end{tabular} & Nyálkahártya \\
\hline & & & & & Mindkettő & Fog \\
\hline & & & & & Maxilla & Kombinált (nyálkahártya/csont/fog) \\
\hline & & & & & \begin{tabular}{|l|} 
Mandibula \\
\end{tabular} & Kombinált (nyálkahártya/csont/fog) \\
\hline & & & & & Mindkettő & Csont \\
\hline & & & & & \begin{tabular}{|l|} 
Mindkettő \\
\end{tabular} & Kombinált (nyálkahártya/fog) \\
\hline & & & & & Mindkettő & Kombinált (nyálkahártya/csont/fog) \\
\hline Ruppin és mtsai. [26] & 2008 & Cadaver & SimPlant & Mindkettő (részleges és teljes foghiány) & Mandibula & Csont \\
\hline Dreiseidler és mtsai. [9] & 2009 & Modell & Nobel Guide & Részleges foghiány & Mindkettő & Fog \\
\hline \multirow[t]{6}{*}{ Ozan és mtsai. [21] } & 2009 & Klinikai & StentCad & Mindkettő (részleges és teljes foghiány) & \begin{tabular}{|l|} 
Mindkettő \\
\end{tabular} & Kombinált (nyálkahártya/csont/fog) \\
\hline & & & & & Maxilla & Kombinált (nyálkahártya/csont/fog) \\
\hline & & & & & \begin{tabular}{|l|} 
Mandibula \\
\end{tabular} & Kombinált (nyálkahártya/csont/fog) \\
\hline & & & & & \begin{tabular}{|l|} 
Mindkettő \\
\end{tabular} & Csont \\
\hline & & & & & Mindkettő & Nyálkahártya \\
\hline & & & & & Mindkettő & Fog \\
\hline \multirow[t]{3}{*}{ Arisan és mtsai. [1] } & 2010 & Klinikai & SimPlant & Mindkettő (részleges és teljes foghiány) & Mindkettő & Nyálkahártya+rögzítőtüske \\
\hline & & & & & & Fog \\
\hline & & & & & & Csont \\
\hline \multirow[t]{3}{*}{ Arisan és mtsai. [1] } & 2010 & Klinikai & StentCad & Mindkettó (részleges és teljes foghiány) & Mindkettő & Nyálkahártya+rögzítőtüske \\
\hline & & & & & Mindkettő & Fog \\
\hline & & & & & \begin{tabular}{|l|} 
Mindkettő \\
\end{tabular} & Csont \\
\hline \multirow[t]{2}{*}{ Nickenig és mtsai. [19] } & 2010 & Klinikai & coDiagnostiX & Részleges foghiány & Mandibula & Fog \\
\hline & & & & Részleges foghiány & Mandibula & Fog \\
\hline \multirow[t]{3}{*}{ Pettersson és mtsai. [23] } & 2012 & Klinikai & Nobel Guide & Teljes foghiány & Mindkettő & Nyálkahártya+rögzítőtüske \\
\hline & & & & & \begin{tabular}{|l|} 
Maxilla \\
\end{tabular} & \\
\hline & & & & & Mandibula & \\
\hline \multirow[t]{3}{*}{ Pettersson és mtsai. [22] } & 2010 & Cadaver & Nobel Guide & Teljes foghiány & \begin{tabular}{|l|} 
Mindkettő \\
\end{tabular} & Nyálkahártya+rögzítőtüske \\
\hline & & & & & \begin{tabular}{|l|} 
Maxilla \\
\end{tabular} & \\
\hline & & & & & \begin{tabular}{|l|} 
Mandibula \\
\end{tabular} & \\
\hline Tahmaseb és mtsai. [30] & 2010 & Modell & Exe-plan & Teljes foghiány & \begin{tabular}{|l|} 
Mandibula \\
\end{tabular} & Mini-implantátum \\
\hline Viegas és mtsai. [36] & 2010 & Modell & NeoGuide & Teljes foghiány & Mandibula & Csont \\
\hline \multirow[t]{3}{*}{ Cassetta és mtsai. [4] } & 2013 & Klinikai & SimPlant & Mindkettő (részleges és teljes foghiány) & \begin{tabular}{|l|} 
Mindkettő \\
\end{tabular} & Kombinált (nyálkahártya/csont/fog) \\
\hline & & & & & & $\begin{array}{l}\text { Kombinált (nyálkahártya/csont) } \\
\text { +rögzítőtüske }\end{array}$ \\
\hline & & & & & & Kombinált (nyálkahártya/csont/fog) \\
\hline \multirow[t]{4}{*}{ Ozan és mtsai. [20] } & 2011 & Klinikai & StentCad & Mindkettő (részleges és teljes foghiány) & Maxilla & Nyálkahártya \\
\hline & & & & & Mandibula & Nyálkahártya \\
\hline & & & & & Maxilla & Nyálkahártya+rögzítőtüske \\
\hline & & & & & Mandibula & Nyálkahártya+rögzítőtüske \\
\hline Platzer és mtsai. [25] & 2011 & Klinikai & SimPlant & Részleges foghiány & Mandibula & Fog \\
\hline \multirow[t]{2}{*}{ Tahmaseb és mtsai. [29] } & 2011 & Modell & Exe-plan & Részleges foghiány & Maxilla & Mini-implantátum \\
\hline & & & & Részleges foghiány & Maxilla & Mini-implantátum \\
\hline \multirow[t]{2}{*}{ Vasak és mtsai.[34] } & 2011 & Klinikai & Nobel Guide & Mindkettő (részleges és teljes foghiány) & Mindkettő & $\begin{array}{l}\text { Kombinált (nyálkahártya/fog) } \\
\text { +rögzítőtüske }\end{array}$ \\
\hline & & & & & Mindkettő & $\begin{array}{l}\text { Kombinált (nyálkahártya/fog) } \\
\text { +rögzítőtüske }\end{array}$ \\
\hline \multirow[t]{2}{*}{ Arisan és mtsai. [2] } & 2012 & Klinikai & SimPlant \&CBCT & Teljes foghiány & Mindkettő & Nyálkahártya+rögzítőtüske \\
\hline & & & SimPlant \& CT & & & \\
\hline Behneke és mtsai. [3] & 2012 & Klinikai & Implant 3D & Részleges foghiány & \begin{tabular}{|l|} 
Mindkettő \\
\end{tabular} & Fog \\
\hline D’Haese és mtsai. [6] & 2012 & Klinikai & Facilitate & Teljes foghiány & Maxilla & Nyálkahártya+rögzítőtüske \\
\hline \multirow[t]{3}{*}{ Di Giacomo és mtsai. [8] } & 2012 & Klinikai & Implant Viewer & Teljes foghiány & Mindkettő & Nyálkahártya+rögzítőtüske \\
\hline & & & & & Maxilla & \\
\hline & & & & & Mandibula & \\
\hline Kuhl és mtsai. [17] & 2012 & Cadaver & coDiagnostiX & Mindkettő (részleges és teljes foghiány) & \begin{tabular}{|l|} 
Mandibula \\
\end{tabular} & Kombinált (nyálkahártya/fog) \\
\hline Soares és mtsai. [27] & 2012 & Modell & NeoGuide & Teljes foghiány & Mandibula & Nyálkahártya+rögzítőtüske \\
\hline
\end{tabular}




\begin{tabular}{|c|c|c|c|c|c|c|c|}
\hline $\begin{array}{c}\text { Implantátum ehelyezés } \\
\text { (SZK = szabadkéz; } \\
\text { S = teljesen sablon által irányított) }\end{array}$ & $\begin{array}{l}\text { Implantátum } \\
\text { szám } \\
\text { (n) }\end{array}$ & Lebenyképzés & $\begin{array}{c}\text { Belépési } \\
\text { eltérés } \\
(\mathrm{mm}) \\
\text { Átlag }\end{array}$ & $\begin{array}{l}\text { Belépési } \\
\text { eltérés } \\
(\mathrm{mm}) \\
\text { SD }\end{array}$ & $\begin{array}{c}\text { Apikális } \\
\text { eltérés } \\
(\mathrm{mm}) \\
\text { Átlag }\end{array}$ & $\begin{array}{l}\text { Apikális } \\
\text { eltérés } \\
(\mathrm{mm}) \\
\text { SD }\end{array}$ & $\begin{array}{c}\text { Szög eltérés (fokokban) átlag } \\
\quad \pm \\
\text { Szög eltérés (fokokban) SD }\end{array}$ \\
\hline$S$ & 10 & Igen & 0,8 & 0,3 & 0,9 & 0,3 & $1,8 \pm 1$ \\
\hline SZK & 21 & Nem & 1,45 & 1,42 & 2,99 & 1,77 & $7,25 \pm 2,67$ \\
\hline $\mathrm{S}$ & 12 & Igen & 1,1 & 0,7 & 1,2 & 0,7 & $1,8 \pm 0,8$ \\
\hline SZK & 94 & Mix & 1,22 & 0,85 & 1,51 & 1 & $4,9 \pm 2,36$ \\
\hline SZK & 65 & Mix & 1,28 & 0,92 & 1,6 & 1,08 & $5,1 \pm 2,59$ \\
\hline SZK & 20 & Mix & 1,23 & 0,67 & 1,59 & 0,74 & $4,78 \pm 1,86$ \\
\hline SZK & 9 & Mix & 0,74 & 0,4 & 0,66 & 0,28 & $3,71 \pm 0,93$ \\
\hline SZK & 23 & Mix & 1,1 & 0,7 & 1,7 & 1 & $4,9 \pm 2,2$ \\
\hline SZK & 26 & Mix & 1,1 & 0,6 & 1,3 & 0,7 & $4,4 \pm 1,6$ \\
\hline SZK & 48 & Mix & 1,04 & 0,56 & 1,57 & 0,97 & $5,31 \pm 0,36$ \\
\hline SZK & 46 & Mix & 1,42 & 1,05 & 1,44 & 1,03 & $4,4 \pm 0,31$ \\
\hline SZK & 45 & $\mathrm{Nem}$ & 1,3 & 1 & 1,6 & 1,5 & $5,1 \pm 2,7$ \\
\hline SZK & 53 & Nem & 1,4 & 1 & 1,4 & 1,7 & $\pm 2,6$ \\
\hline SZK & 41 & Igen & 1,1 & 0,6 & 1,4 & 1 & $4,7 \pm 2$ \\
\hline SZK & 40 & Nem & 1,5 & 0,8 & & & $7,9 \pm 5$ \\
\hline $\mathrm{S}$ & 24 & $\mathrm{Nem}$ & 0,22 & 0,099 & 0,34 & 0,15 & $1,09 \pm 0,51$ \\
\hline SZK & 110 & Mix & 1,11 & 0,7 & 1,41 & 0,9 & $4,1 \pm 2,3$ \\
\hline SZK & 58 & Mix & 0,95 & 0,5 & 1,41 & 1 & $4,85 \pm 2,4$ \\
\hline SZK & 52 & Mix & 1,28 & 0,9 & 1,4 & 0,9 & $3,32 \pm 1,9$ \\
\hline SZK & 50 & Nem & 1,28 & 0,9 & 1,57 & 0,9 & $4,63 \pm 2,6$ \\
\hline SZK & 30 & Igen & 1,06 & 0,6 & 1,6 & 1 & $4,51 \pm 2,1$ \\
\hline SZK & 30 & Igen & 0,87 & 0,4 & 0,96 & 0,6 & $2,91 \pm 1,3$ \\
\hline $\mathrm{S}$ & 54 & Igen & 0,7 & 0,13 & 0,76 & 0,15 & $2,9 \pm 0,39$ \\
\hline $\mathrm{S}$ & 50 & Igen & 0,81 & 0,33 & 1,01 & 0,4 & $3,39 \pm 0,84$ \\
\hline SZK & 43 & $\mathrm{Nem}$ & 1,56 & 0,25 & 1,86 & 0,4 & $4,73 \pm 1,28$ \\
\hline SZK & 43 & Igen & 1,24 & 0,51 & 1,4 & 0,47 & $4,23 \pm 0,72$ \\
\hline SZK & 45 & Igen & 1,31 & 0,59 & 1,62 & 0,54 & $3,5 \pm 1,38$ \\
\hline SZK & 44 & $\mathrm{Nem}$ & 1,7 & 0,52 & 1,99 & 0,64 & $\pm 1,66$ \\
\hline SZK & 23 & Igen & 0,9 & 1,06 & 0,6 & 0,57 & $4,2 \pm 3,04$ \\
\hline SZK & 23 & Igen & 0,9 & 1,22 & 0,9 & 0,94 & $4,2 \pm 3,04$ \\
\hline \multirow[t]{3}{*}{$\mathrm{S}$} & 139 & Igen & 0,95 & 0,55 & 1,22 & 0,63 & $2,76 \pm 1,76$ \\
\hline & 89 & Igen & 0,95 & 0,53 & 1,15 & 0,51 & $2,71 \pm 1,41$ \\
\hline & 50 & Igen & 0,96 & 0,57 & 1,35 & 0,8 & $2,85 \pm 2,27$ \\
\hline \multirow[t]{3}{*}{$\mathrm{S}$} & 145 & Igen & 1,06 & 0,58 & 1,25 & 0,68 & $2,64 \pm 1,42$ \\
\hline & 78 & Igen & 0,83 & 0,57 & 0,96 & 0,5 & $2,02 \pm 0,66$ \\
\hline & 67 & Igen & 1,05 & 0,47 & 1,24 & 0,58 & $2,46 \pm 0,67$ \\
\hline $\mathrm{s}$ & 6 & Modell & 0,055 & 0,032 & & & \\
\hline \multirow[t]{2}{*}{$\mathrm{S}$} & 11 & Modell & 0,37 & 0,2 & 0,41 & 0,22 & $0,7 \pm 0,3$ \\
\hline & 11 & Modell & 0,3 & 0,17 & 0,36 & 0,25 & $1,45 \pm 0,89$ \\
\hline SZK & 116 & 0,81 & 1,47 & 0,68 & 1,83 & 1,03 & $5,09 \pm 3,7$ \\
\hline $\mathrm{S}$ & 57 & 0,84 & 1,49 & 0,63 & 1,9 & 0,83 & $3,93 \pm 2,34$ \\
\hline $\mathrm{S}$ & 54 & 0,83 & 1,55 & 0,59 & 2,05 & 0,89 & $5,46 \pm 3,38$ \\
\hline SZK & 80 & Igen & & & & & $6,29 \pm 2,12$ \\
\hline SZK & 44 & Igen & & & & & $4,35 \pm 1,8$ \\
\hline $\mathrm{S}$ & 49 & Igen & & & & & $3,91 \pm 1,21$ \\
\hline $\mathrm{S}$ & 43 & Igen & & & & & $3,55 \pm 1,08$ \\
\hline $\mathrm{S}$ & 15 & Igen & 0,27 & 0,19 & & & \\
\hline$S$ & 15 & Igen & 0,15 & 0,13 & & & \\
\hline$S$ & 4 & Modell & 0,027 & 0,015 & & & \\
\hline$S$ & 4 & Modell & 0,025 & 0,022 & & & \\
\hline S & 86 & Igen & 0,46 & 0,35 & 0,7 & 0,49 & $3,53 \pm$ \\
\hline $\mathrm{S}$ & 86 & Igen & 0,43 & 0,32 & 0,59 & 0,44 & \\
\hline \multirow[t]{2}{*}{$\mathrm{s}$} & 52 & Igen & 0,81 & 0,32 & 0,81 & 0,32 & $3,47 \pm$ \\
\hline & 50 & Igen & 0,75 & 0,32 & 0,8 & 0,35 & $3,3 \pm$ \\
\hline $\mathrm{S}$ & 24 & Mix & 0,21 & 0,19 & 0,28 & 0,2 & $1,49 \pm$ \\
\hline SZK & 86 & Mix & 0,3 & 0,21 & 0,47 & 0,27 & $2,06 \pm$ \\
\hline $\mathrm{s}$ & 78 & Igen & 0,91 & 0,44 & 1,13 & 0,52 & $2,6 \pm$ \\
\hline \multirow[t]{3}{*}{ SZK } & 60 & Igen & 1,35 & 0,65 & 1,79 & 1,01 & $6,53 \pm$ \\
\hline & 22 & Igen & 1,51 & 0,62 & 1,86 & 1,07 & $8,54 \pm$ \\
\hline & 38 & Igen & 1,26 & 0,66 & 1,75 & 0,99 & $5,37 \pm$ \\
\hline SZK & 19 & Igen & 1,56 & 0,53 & 1,84 & 0,41 & $4,3 \pm$ \\
\hline $\mathrm{S}$ & 19 & Igen & 1,52 & 0,81 & 1,55 & 0,68 & $3,6 \pm$ \\
\hline $\mathrm{s}$ & 18 & Igen & 1,38 & 0,42 & 1,39 & 0,4 & $2,16 \pm$ \\
\hline
\end{tabular}




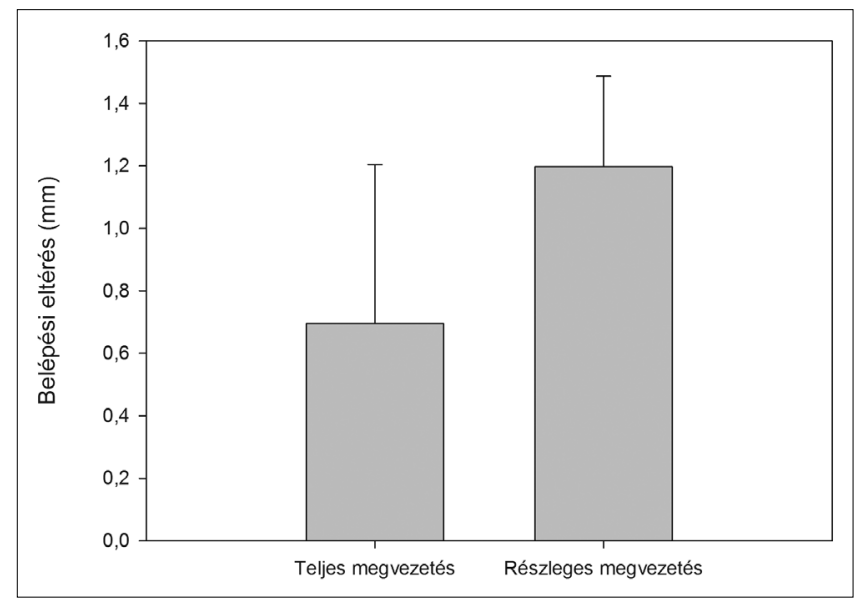

5. ábra: Belépési eltérés

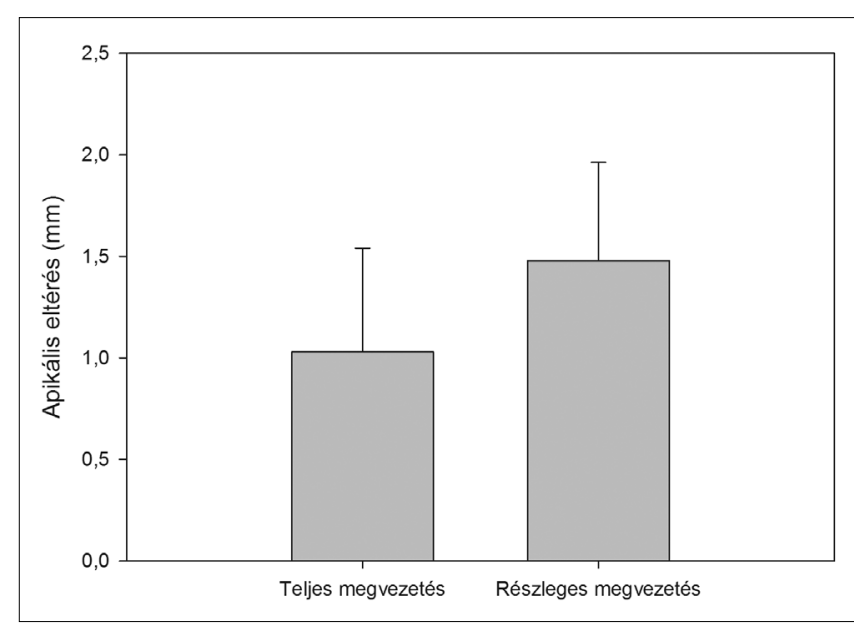

6. ábra: Apikális eltérés

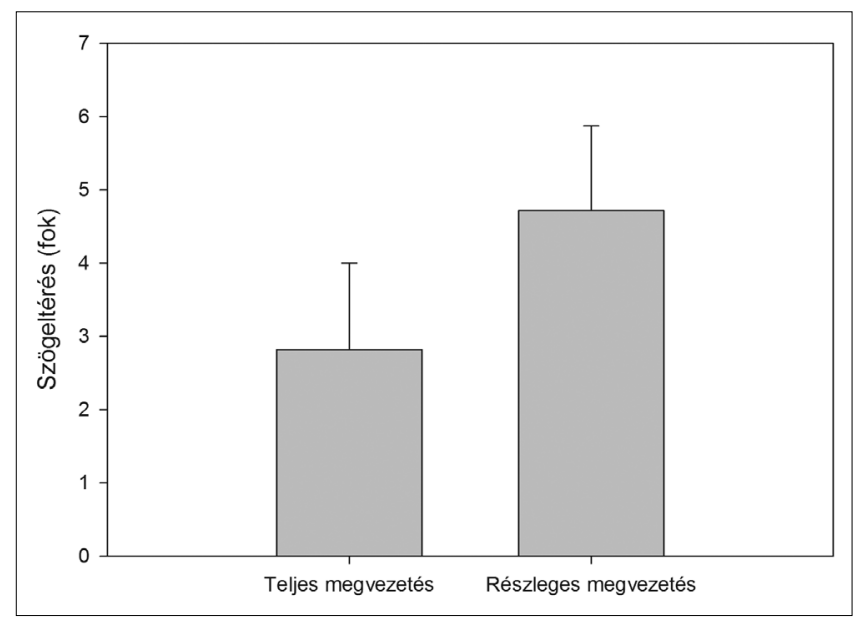

7. ábra: Szögeltérés

Apikális eltérésekről szintén 74 esetben számoltak be. Az átlagok értékei 0,34 és 1,39 mm közé estek. A szögek összehasonlításából kapott értékek átlagai $0,7^{\circ}$ és $2,16^{\circ}$ között voltak.
Cadaver vizsgálatok: 390 implantátumot vizsgálva a legalacsonyabb átlageltérés 0,8 , míg a legmagasabb $1,56 \mathrm{~mm}$ volt a belépési mérópont eltérésének tekintetében. Az apikális mérőpontok vonatkozásában a minimum 0,9 , a maximum $1,84 \mathrm{~mm}$ volt. A szögek közötti átlagos eltérésekről elmondható, hogy a legkisebb $1,8^{\circ}$, a legmagasabb $7,9^{\circ}$ volt.

Klinikai elemzések: Az általunk elemzett irodalomban összesen 2355 behelyezett implantátumra vonatkozólag van klinikai adatunk. Ezen eredmények közül az implantátumok belépési értékeinek átlagai 0,15 , és $1,7 \mathrm{~mm}$ között helyezkedtek el. Az apikális eltérések átlagai 0,28 és 2,99 mm között változtak.

A szögeltérések tartománya $1,49^{\circ}$ és $8,54^{\circ}$ közé esett. Kapott eredményeinket a 2, 3, 4. ábrákon foglaltuk össze.

Az összes tanulmány együttes elemzése során kapott eredményeink alapján elmondhatjuk:

2819 esetet összesítve a belépési értékek átlaga $0,98 \mathrm{~mm}$ volt. Az apikális eltéréseket figyelembe véve ez a szám $1,29 \mathrm{~mm}$ volt, míg a szögeltéréseket vizsgálva 3,96ºt kaptunk eredményül.

További statisztikai elemzéseink során a következő eredmények születtek: a transzgingivális és a lebenyképzéssel járó mútéti feltárás során a korábban már említett három mérőszám (belépési pont, apikális pont, szögeltérés) esetében nem volt szignifikáns különbség. Az állcsontok, a sablonok megtámasztása, és a foghiányok összehasonlítása folyamán szignifikáns eltérés szintén nem volt tapasztalható. A teljes és a részleges megvezetés összehasonlítása alapján mindhárom mérőszám szignifikánsan pontosabb eredményeket mutatott, a sablon által végig kontrollált implantátum behelyezés esetében (5-7. ábra).

\section{Megbeszélés}

Áttekintő irodalmi tanulmányunk során elsődlegesen a pontossági értékek összehasonlító elemzését végeztük el. A számítógépes tervezés által irányított implantációs beavatkozások lehetőséget adnak a lebenyképzési eljárások nélküli alkalmazásra is. Olyan esetekre gondolunk itt, amikor a rendelkezésre álló csont menynyisége és minősége korlátokat szab és/vagy valamilyen elkerülendő anatómiai struktúra található a mútéti terület közelében (Id. nervus alveolaris inferior, sinus maxillaris). Fenti okokból kifolyólag kiemelt jelentőséggel bír, hogy az egyes rendszerek használata közben milyen eltérések adódnak a tervezett, és a megvalósult pozíciók között. Di Giacomo és mtsai szerint az implantáció során bekövetkező sebészi sablon mozgása elsődlegesen felelős az észlelt maximális eltérésekért [7]. Ezen elmozdulások kiküszöbölése érdekében a lebeny nélküli mútét helyett, egyoldali csont-megtámasztású sablonok készítését javasolták. Egy másik 
lehetőség a teljes fogatlan állcsonton alkalmazott sebészeti sablonok pontosságának növelésére a mini implantátumok átmeneti alkalmazása. A sablonok megtámasztása egyértelmű hatással van a pontosságra. Tahmaseb és mtsai kimutatták, hogy a mini implantátumok által megtámasztott sablonok a legpontosabbak [31]. A 2014. évi ITI elemzésből is látszik, hogy a csonton elhorgonyzott sablonok pontatlanabbak voltak, mint a mini implantátumon megtámasztottak. Ugyanezen vizsgálat eredménye, hogy a lebenyképzéssel járó beavatkozások kisebb pontosságot eredményeztek úgy, hogy ott a legtöbb esetben csak csonton támaszkodó sablonokat használtak [31].

Ozan és mtsai szignifikáns eltérést tapasztaltak a két állcsont között. Az alsó állcsont tekintetében az eredmények pontosabbak voltak [20]. Pettersson és mtsai [22] ennek éppen ellenkezőjét írták le, azaz a mandibulában jelentősen magasabb devianciákról számoltak be. Saját analízisünk során az egyes állcsontok tekintetében nagy eltérés nem volt tapasztalható.

Szignifikáns eltérést sikerült azonban kimutatni az egyes behelyezési (részlegesen, és teljesen sablon által irányított) módszerek között mind a három mérőszám esetében (apikális távolság, belépési eltérés, szögeltérés), ami egyezik az irodalomban található adatokkal [36]. Ezek alapján elmondható, hogy a módszer precizitásnövelésének egyik módja biztosan a teljes sablon által irányított rendszerek használata. Továbbá az irodalmi adatok tükrében elmondható, hogy a rendszerek jelenleg 1,5 mm-es pontatlansággal rendelkeznek, ami egyértelműen kevesebb, mint a hagyományos sebészeti eljárások keretein belül tapasztalt differencia [35].

A jövő kutatási területeinek a sablon által történő implantációs folyamatok egyszerűsítésére, fokozott pontosságára és biztonságára kell irányulnia. Ezenkívül az implantációval kapcsolatban alkalmazott képalkotó eljárások hatékonyságát (pontosabb képfelbontás, csökkentett sugárterhelés) is növelni kell. Az egyes paraméterek további vizsgálatára egy, illetve több vizsgálati központban zajló randomizált, kontrollált klinikai kutatásra van szükség, amely megfelel az evidencia alapú tudás követelményeinek. Kutatócsoportunk a jövőben tervezi a sablon által irányított implantációs sebészeti eljárások további klinikai aspektusainak vizsgálatát is.

\section{Irodalom}

1. Arisan V, Karabuda ZC, Ozdemir T: Accuracy of two stereolithographic guide systems for computer-aided implant placement: a computed tomography-based clinical comparative study. J Periodontol. 2010; 81: 43-51.

2. Arisan V, Karabuda ZC, Piskin B, Ozdemir T: Conventional multislice computed tomography (CT) and cone-beam CT (CBCT) for computer-aided implant placement. Part II: reliability of mucosasupported stereolithographic guides. Clin Implant Dent Relat Res. 2013; 15: 907-917.

3. Behneke A, Burwinkel M, Behneke N: Factors influencing transfer accuracy of cone beam CT-derived template-based implant placement. Clin Oral Implants Res. 2012; 23: 416-423.
4. Cassetta M, Stefaneli lV, Giansanti M, Di Mambro A, Calasso S: Accuracy of a computer-aided implant surgical technique. Int $J$ Periodontics Restorative Dent. 2013; 33: 317-325.

5. Chiapasco M, Zaniboni M, Boisco M: Augmentation procedures for the rehabilitation of deficient edentulous ridges with oral implants. Clin Oral Implants Res. 2006; 17 Suppl 2: 136-159.

6. D'Haese J, Van De Velde T, Elaut L, De Bruyn H: A prospective study on the accuracy of mucosally supported stereolithographic surgical guides in fully edentulous maxillae. Clin Implant Dent Relat Res. 2012; 14: 293-303.

7. Di Giacomo GA, Cury PR, de Araujo NS, Sendyk WR, Sendyk CL: Clinical application of stereolithographic surgical guides for implant placement: preliminary results. J Periodontol. 2005; 76: 503-507.

8. Di Giacomo GA, da Silva JV, da Silva AM, Paschoal GH, Cury PR, SzARF G: Accuracy and complications of computer-designed selective laser sintering surgical guides for flapless dental implant placement and immediate definitive prosthesis installation. $J$ Periodontol. 2012; 83: 410-419.

9. Dreiseidler T, Neugebauer J, Ritter L, Lingohr T, Rothamel D, MisCHKowsKI RA, et al.: Accuracy of a newly developed integrated system for dental implant planning. Clin Oral Implants Res. 2009; 20: 1191-1199.

10. Ersoy AE, Turkyilmaz I, Ozan O, McGlumphy EA: Reliability of implant placement with stereolithographic surgical guides generated from computed tomography: clinical data from 94 implants. J Periodontol. 2008; 79: 1339-1345.

11. Guerrero ME, Jacobs R, Loubele M, Schutyser $F$, Suetens $P$, van STEENBERGHE D: State-of-the-art on cone beam CT imaging for preoperative planning of implant placement. Clin Oral Investig. 2006; 10: 1-7.

12. Hammerle $\mathrm{CH}$, Cordaro L, van Assche N, Benic Gi, Bornstein M, GAMPER $F$, et al.: Digital technologies to support planning, treatment, and fabrication processes and outcome assessments in implant dentistry. Summary and consensus statements. The 4th EAO consensus conference 2015. Clin Oral Implants Res. 2015; 26 Suppl 11: 97-101.

13. Hammerle CH, Jung Re, Feloutzis A: A systematic review of the survival of implants in bone sites augmented with barrier membranes (guided bone regeneration) in partially edentulous patients. J Clin Periodontol. 2002; 29 Suppl 3: 226-31; discussion 32-33.

14. Harris D, Horner K, Grondahl K, Jacobs R, Helmrot E, Benic Gi, et al.: E.A.O. guidelines for the use of diagnostic imaging in implant dentistry 2011. A consensus workshop organized by the European Association for Osseointegration at the Medical University of Warsaw. Clin Oral Implants Res. 2012; 23: 1243-1253.

15. Jung Re, Pjetursson BE, Glauser R, Zembic A, Zwahlen M, Lang NP: A systematic review of the 5-year survival and complication rates of implant-supported single crowns. Clin Oral Implants Res. 2008; 19: 119-130.

16. Jung Re, Schneider D, Ganeles J, Wismeijer D, Zwahlen M, HamMERLE CH, et al.: Computer technology applications in surgical implant dentistry: a systematic review. Int J Oral Maxillofac Implants. 2009; 24 Suppl: 92-109.

17. Kuhl S, Zurcher S, Mahid T, Muller-Gerbl M, Filippi A, Cattin P: Accuracy of full guided vs. half-guided implant surgery. Clin Oral Implants Res. 2013; 24: 763-769.

18. Loubele M, Bogaerts R, Van Diuck E, Pauwels R, Vanheusden $S$, SUETENS $P$, et al.: Comparison between effective radiation dose of CBCT and MSCT scanners for dentomaxillofacial applications. Eur J Radiol. 2009; 71: 461-468.

19. Nickenig HJ, Wichmann M, Hamel J, Schlegel KA, Eitner S: Evaluation of the difference in accuracy between implant placement by virtual planning data and surgical guide templates versus the conventional free-hand method - a combined in vivo - in vitro technique using cone-beam CT (Part II). J Craniomaxillofac Surg. 2010; 38: 488-493.

20. Ozan O, Orhan K, Turkyilmaz I: Correlation between bone density 
and angular deviation of implants placed using CT-generated surgical guides. J Craniofac Surg. 2011; 22: 1755-1761.

21. Ozan O, Turkyilmaz I, Ersoy AE, McGlumphy EA, Rosenstiel SF: Clinical accuracy of 3 different types of computed tomographyderived stereolithographic surgical guides in implant placement. J Oral Maxillofac Surg. 2009; 67: 394-401.

22. Pettersson A, Kero T, Gillot L, Cannas B, Faldt J, Soderberg R, et al.: Accuracy of CAD/CAM-guided surgical template implant surgery on human cadavers: Part I. J Prosthet Dent. 2010; 103 334-342.

23. Pettersson A, Komiyama A, Hultin M, Nasstrom K, Klinge B: Accuracy of virtually planned and template guided implant surgery on edentate patients. Clin Implant Dent Relat Res. 2012; 14: 527537.

24. Puetursson Be, Tan K, Lang NP, Bragger U, Egger M, Zwahlen M: A systematic review of the survival and complication rates of fixed partial dentures (FPDs) after an observation period of at least 5 years. Clin Oral Implants Res. 2004; 15: 667-676.

25. Platzer S, Bertha G, Heschl A, Wegscheider WA, Lorenzoni M Three-dimensional accuracy of guided implant placement: indirect assessment of clinical outcomes. Clin Implant Dent Relat Res. 2013; 15: 724-734.

26. Ruppin J, Popovic A, Strauss M, Spuntrup E, Steiner A, Stoll C: Evaluation of the accuracy of three different computer-aided surgery systems in dental implantology: optical tracking vs. stereolithographic splint systems. Clin Oral Implants Res. 2008; 19: 709-716.

27. Soares MM, Harari ND, Cardoso ES, Manso MC, Conz MB, VidiGAL GM, JR.: An in vitro model to evaluate the accuracy of guided surgery systems. Int J Oral Maxillofac Implants. 2012; 27: 824-831.

28. Tahmaseb A, De Clemck R, Aartman I, Wismeijer D: Digital protocol for reference-based guided surgery and immediate loading a prospective clinical study. Int J Oral Maxillofac Implants. 2012; 27: $1258-1270$

29. Tahmaseb A, De Clerck R, Eckert S, Wismeijer D: Referencebased digital concept to restore partially edentulous patients fol- lowing an immediate loading protocol: a pilot study. Int J Oral Maxillofac Implants. 2011; 26: 707-717.

30. Tahmaseb A, van de Weijden JJ, Mercelis P, De Clerck R, WisMEIJER D: Parameters of passive fit using a new technique to mill implant-supported superstructures: an in vitro study of a novel three-dimensional force measurement-misfit method. Int $\mathrm{J}$ Oral Maxillofac Implants. 2010; 25: 247-257.

31. Tahmaseb A, WismeiJer D, Coucke W, Derksen W: Computer technology applications in surgical implant dentistry: a systematic review. Int J Oral Maxillofac Implants. 2014; 29 Suppl: 25-42.

32. Van Assche N, van Steenberghe D, Guerrero ME, Hirsch E, SCHUTYSER F, QUIRYNEN M, et al.: Accuracy of implant placement based on pre-surgical planning of three-dimensional cone-beam images: a pilot study. J Clin Periodontol. 2007; 34: 816-821.

33. Van Steenberghe D, Naert I, Andersson M, Brajnovic I, Van Cleynenbreugel J, Suetens P: A custom template and definitive prosthesis allowing immediate implant loading in the maxilla: a clinical report. Int J Oral Maxillofac Implants. 2002; 17: 663-670.

34. Vasak C, Watzak G, Gahleitner A, Strbac G, Schemper M, ZechNER W: Computed tomography-based evaluation of template (NobelGuide)-guided implant positions: a prospective radiological study. Clin Oral Implants Res. 2011; 22: 1157-1163.

35. Vercruyssen M, De Laat A, Coucke W, Quirynen M: An RCT comparing patient-centred outcome variables of guided surgery (bone or mucosa supported) with conventional implant placement. J Clin Periodontol. 2014; 41: 724-732.

36. Vercruyssen M, Laleman I, Jacobs R, Quirynen M: Computer-supported implant planning and guided surgery: a narrative review. Clin Oral Implants Res. 2015; 26 Suppl 11: 69-76.

37. Viegas VN, Dutra V, Pagnoncelli RM, de Oliveira MG: Transference of virtual planning and planning over biomedical prototypes for dental implant placement using guided surgery. Clin Oral Implants Res. 2010; 21: 290-295.

38. Widmann G, Stoffner R, Schullian P, Widmann R, Keiler M, ZanGERL $A$, et al.: Comparison of the accuracy of invasive and noninvasive registration methods for image-guided oral implant surgery. Int J Oral Maxillofac Implants. 2010; 25: 491-498.

\section{Barrak I, Varga E JR, PiffKó J}

\section{Navigation in implantology: Accuracy assessment regarding the literature}

Our objective was to assess the literature regarding the accuracy of the different static guided systems. After applying electronic literature search we found 661 articles. After reviewing 139 articles, the authors chose 52 articles for full-text evaluation. 24 studies involved accuracy measurements. Fourteen of our selected references were clinical and ten of them were in vitro (modell or cadaver). Variance-analysis (Tukey's post-hoc test; $p<0,05$ ) was conducted to summarize the selected publications. Regarding 2819 results the average mean error at the entry point was $0,98 \mathrm{~mm}$. At the level of the apex the average deviation was $1,29 \mathrm{~mm}$ while the mean of the angular deviation was $3,96^{\circ}$. Significant difference could be observed between the two methods of implant placement (partially and fully guided sequence) in terms of deviation at the entry point, apex and angular deviation. Different levels of quality and quantity of evidence were available for assessing the accuracy of the different computer-assisted implant placement. The rapidly evolving field of digital dentistry and the new developments will further improve the accuracy of guided implant placement. In the interest of being able to draw dependable conclusions and for the further evaluation of the parameters used for accuracy measurements, randomized, controlled single or multi-centered clinical trials are necessary.

Keywords: computer planning, dental implants, guided surgery, surgical guide 